\title{
Introduction: Anger, media and feminism: the gender politics of mediated rage
}

Jilly Boyce Kay

University of Leicester

Over the last few years, we have been witnessing an extraordinary new visibility of women's anger. Since the election of Trump in the US and the unprecedented disclosures of gendered abuse that characterised \#MeToo, female anger seems to be registering in ways that it has seldom done in recent decades. As Rebecca Traister $(2018,2)$ puts it in her bestselling book Good and Mad: The Revolutionary Power of Women's Anger --- itself a part of the remarkable boom in publishing on female fury --- "The contemporary reemergence of women's rage as a mass impulse comes after decades of feminist deep freeze". Significantly, this new registering of rage is occurring not only in the sphere of politics and protest as they are normatively understood; women's anger is increasingly legible within popular and commercial cultural forms. Rage, it seems, is becoming all the rage. In relation to television, the feminist writer Laura Bates (2018) has pointed to "a plethora of furious female on-screen heroines, from tough-talking survivor Jessica Jones to rebel handmaid Offred". Elsewhere, I have suggested that we are witnessing a "celebritisation" of anger, in which globalised media culture appears to be newly accommodating of (certain kinds of) female fury in the wake of \#MeToo, as part of popular culture's broader turn to “wokeness” (Jilly Boyce Kay 2019).

Given that, within the long history of western civilisation, women's anger has been construed as deviant, monstrous or otherwise taboo, this is --- we might say --- quite something. It appears to represent nothing less than a qualitative shift in the affective rules 
that govern public culture. If popular feminism has hitherto been "decidedly not angry" (Sarah Banet-Weiser 2018, loc 480) and if rageful "killjoys" (Sara Ahmed 2017) have until now been unwelcome or admonished in the public sphere, then what should we make of this new visibility --- we could even say popularity --- of female anger? Something is clearly afoot --- the "feeling rules" of popular culture are assuredly shifting. But what political potential does this hold? How quickly should we move to celebrate this apparent new openness to women's anger? Does this represent a genuine transformation in gender power relations, or is it yet another case of capitalist media culture's boundless capacities for adaptability, recalibration and co-optation?

This special issue of Commentary and Criticism is an attempt to begin to think through the complex politics of mediated anger from within the critical context of feminist media studies. In their essay on the female actor Uma Thurman's rage against sexual violence and coercion --- an early "flashpoint” (Sarah Banet-Weiser 2018a) of \#MeToo --- Shani Orgad and Rosalind Gill argue that the mediation of Thurman's anger operated not so much as an "unleashing" of rage (a rage whose energy and force could be harnessed for political change), but rather as a series of "safety valves" (Lauren Berlant 2008) that allowed for a careful regulation of female anger, such that it did not represent any real threat to the patriarchal order. Thurman's anger was "re-rendered in individual terms", which should be understood as part of the insidious ways in which women's anger is so often "put back in its place”. In Jilly Boyce Kay and Sarah Banet-Weiser's essay, we consider the public testimonies given by Christine Blasey Ford and Brett Kavanaugh in 2018, and Anita Hill and Clarence Thomas in 1991 --- both of which involved claims of sexual assault by women against powerful men in the US. We argue that these constitute clear cases of "affective injustice" (Amia Srinivasan 2018) whereby victims of injustice, in their need to appear "credible", are effectively rendered unable to express anger, even when anger would be a 
highly justified response. Finally, Helen Wood's essay points to some of the more hopeful ways in which particular forms of women's anger might escape or exceed the highly constraining "feeling rules" of media culture. She considers how the increasing prevalence of the word "fuck" in feminist protest --- and in media culture more broadly --- might be understood as part of a growing form of "irreverent rage" that is linked to a decline in class deference. This irreverent rage --- which she explores through the angry speech (frequently framed as "rants") of politicians Jess Philips and Alexandra Ocasio-Cortez --- is able to "catch on" in a hyper-affective networked media culture. Wood sees the ubiquity of "fucks" as "a symptom of more hopeful shifts in the denial of regulatory power --- shifts that also offer forms of intersectional and affective connection against that regulatory power”. In a context where women are so often compelled to hyper-regulate their anger (it is significant that Thurman and Blasey Ford were both lauded for appearing so "composed" and "in control" of their anger), is it possible that loudly and irreverently giving no fucks might, just might, offer us a kind of political "superpower"? Wood's essay prompts us to think about how we might find chinks in the armour of affective injustice, to find ways out of or around the double-bind that women are in when it comes to the public expression of anger.

\section{Feminist media studies: it's time to get angry again (again)}

A search for "anger" or "angry" in the titles of articles published in the entire archive of Feminist Media Studies returns only four results (Rosalind Gill 2011; Rosie White 2013; Na’ama Klorman-Eraqi 2017; Amy Shields Dobson and Akane Kanai 2018). Interestingly, "anger" seems never to have been used as a keyword for an article in the entire history of the

journal. Of course, this lexical absence does not mean that anger has not been fundamental to the field of feminist media studies. It may be mostly unnamed as such, but surely anger has 
been a key motivating and sustaining force in our collective scholarship, even if it may ebb and flow in its intensity, and come to the fore more clearly in certain writings and at certain times. Nonetheless, it is still telling that anger has rarely been interrogated and analysed as a concept or category in its own right.

In 2011, on the occasion of this journal's tenth birthday, Rosalind Gill $(2011,68)$ memorably concluded her article with the rallying call: "It is time to get angry again." Reflecting back on this, eight years later, what has changed? Arguably, anger is no longer something that we need to call forth or implore one another to summon: it is palpably here, as a "mass impulse" within the media that we study, as well as in our own individual and collective experiences and feminist politics. Perhaps the question now is not so much how to

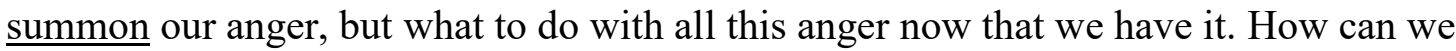
channel and harness this rage? As feminist thinkers such as Audre Lorde (1997) have so powerfully taught us, anger can be energising - it is a resource for feminist activism and thinking. How can feminist media theory and research help us to save this emotional and political resource from being dissipated through the "safety valves" that Gill and Orgad identify, or driven away by the shame that still attaches to women's anger in a media culture that is deeply affectively unjust? And how might we help cultivate and sustain a collective feminist rage in a context of an increasingly individualised higher education that seems to militate against this very possibility?

\section{Feminist communities of anger and re(s)pair}

The motivation for this special section on anger came out of conversations in the Media and Gender Research Group, which was set up in 2014 at the University of Leicester but has members and friends from across the Midlands, the UK and the wider, transnational feminist 
media studies community. In our meetings held in recent months, we have found ourselves consistently drawn to the topic of anger. The "mass impulse" of women's rage that is coursing through media culture has also found expression in our scholarly and personal conversations: there is just so much to be angry about. Is it that we hadn't noticed before? Or is that we had, but that the changed affective mood meant that we were now suddenly able to articulate our anger, to share it, and in doing so recognise what a collective feeling and experience anger is? In any case, now that we have started, it is difficult to stop. Talking

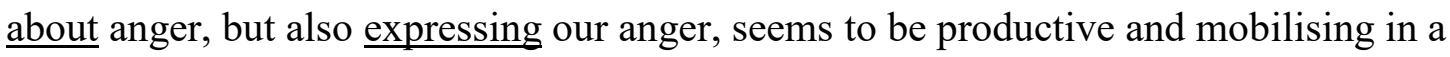
context where emotional energy is otherwise so depleted, and the mustering of hope is otherwise so difficult to achieve. Perhaps it is because of the unleashing of anger that the words "patriarchy", "sexism" and "misogyny" have re-entered our feminist vocabularies, as problems to be named: anger has given us the conviction to say these words again.

In November 2018, the Media and Gender group held a book launch for three new feminist monographs: Melanie Kennedy's (2018) Tweenhood: Femininity and Celebrity in

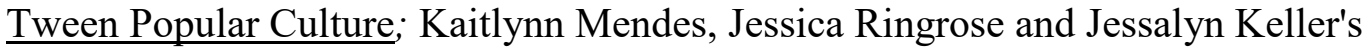
(2018) Digital Feminist Activism: Girls and Women Fight Back Against Rape Culture; and Sarah Banet-Weiser's (2018) Empowered: Popular Feminism and Popular Misogyny. At this launch, the conversation again turned to anger. It also turned to despair, and to how it is so difficult to sustain hope in a world that seems to be crumbling around us, as well as how doing feminist research that entails immersion in cultures of misogyny and sexism can sometimes be deeply painful and overwhelming. How to keep on keeping on? The Media and Gender group is an invaluable community in so many ways: for sharing knowledge and resources, for discussing new feminist scholarship and activism, for giving feedback on one another's work, for providing a generative space at the intersections of the personal and political, and for acting as a haven of intellectual discussion and exploration in a heartless 
world of academic hyper-individualisation and metricisation. Crucially, it has also been a space for thinking through how we might harness anger collectively for the purposes of feminism and social justice ${ }^{1}$.

Sarah Banet-Weiser notes in the introduction to Empowered that "this is the angriest book I have ever written" --- but also that it is "the most hopeful" (2018, loc 217). She also notes how in writing it, she was often "in tears, or sick to my stomach, or generally in despair" (loc 95); and yet how, at the same time, she was motivated by a sense of urgency born out of the political importance of her subject matter. What is the relationship between anger and hope --- as well as hope and despair --- that seems increasingly important to feminist scholarship? In our essay, Sarah Banet-Weiser and I suggest that the $15^{\text {th }}$ century word respair is an apt way of thinking through the politics of despair and hope; we suggest that respair is a kind of hope that does not disavow anger and despair, but rather recognises that both are deeply necessary for meaningful political change: it is about "staying with the trouble, sticking with the mess, and committing to the hard work of repair collectively, not individually". The Media and Gender group is one such community of respair in which anger, humour, care, hope and despair collide: facing up to the mess that we're in can be affirming if it is done collectively.

\footnotetext{
${ }^{1}$ Projects generated from, or with productive affinities to the conversations around anger in the Media and Gender research group include (to name just a few): Mette Lundsfryd's (2017) work on the anger and resistance of women of Palestinian and Syrian heritage; Anna Zsubori (2018) has written about the attack on gender studies in Hungary; Kaitlynn Mendes is starting new research on toxic masculinity, and turning her attention to the role men play in preventing (sexual) violence. She is "angry that the focus is all about women and what women can do to stop being victims, or be better at playing the role of victim. I am also turning my attention to articulations of anger in digital feminist activism (e.g. people's disclosures of violence/abuse/harassment frequently recount their anger at having gone through these experiences but also how others responded (often with disbelief of blame for them)." Katie Moylan is working on a project on transcultural and utopian pedagogy, drawing on students' radio shows and in particular a student feminist show. Claire Sedgwick is writing a book entitled Feminist Media: From the Second Wave to the Digital Age. My own forthcoming book Media, Gender and Voice: Communicative Injustice and Public Speech is deeply influenced by the many conversations I have had within the Media and Gender group ---one of the few spaces where I do not experience the affective injustices that so often attend speaking out.
} 


\section{Unequal angers}

As Audre Lorde has taught us, anger need not be destructive, but generative --- but it must first of all be expressed in order to serve political justice: she said memorably that "anger has eaten clefts into my living only when it remained unspoken, useless to anyone" $(1997,116)$. The first step, then, in using anger for social and political justice ends, is to speak of it. But to "unleash" anger cannot merely be an individualised, cathartic release that makes us feel better; as well as using anger as a resource against injustice, we must also be prepared to deal constructively and non-defensively with anger that is directed at those of us who are privileged or otherwise complicit in systems of oppression (whether we are conscious of it or not). Lorde asked (at a women's conference in 1981): "What women here is so enamoured of her own oppression that she cannot see her heel print upon another woman's face?" (Lorde 1997, 284); as such, any feminist politics of anger must also involve facing towards the "cold winds of self-scrutiny". This must also involve a recognition that not all angers are morally equal, and that there are many manifestations of "women's anger" that are profoundly antifeminist, including the increasing numbers of women operating within far right parties, or the strategic, conservative outrage of commentators such as Katie Hopkins or Sarah Vine. Furthermore, anger that identifies itself as "feminist" --- such as that which is directed towards transwomen in the name of "gender critical" feminism --- should alert us to the fact that we cannot simply valorise all manifestations of "feminist" rage. A feminist politics of anger must take all of these qualifiers and complexities into account, and be prepared to distinguish between angers we will support and angers we will not.

As scholars of feminist media studies, I would suggest that we have an important contribution to make to the burgeoning field of inquiry around gender, feminism and anger; 
surely there is no way of understanding how anger operates in contemporary politics and culture without recourse to feminist media theory. This special issue of Commentary and Criticism is one attempt to explore how anger is gendered and mediated; the collected essays point to some key questions that might underpin future analyses of media, gender and anger, including: whose anger is legible within media culture? On what terms is it made visible? Whose anger is rendered invisible and/or illegitimate? Why do some angry subjects or manifestations of rage gain political traction while others seem to remain at the level of visibility only? And what hopeful instances can we identify where feminist anger escapes, exceeds or destabilises the "feeling rules" of post-feminist media culture?

The gender politics of mediated anger require further, ongoing, intersectional feminist analysis; there are many more questions to be asked, contexts to consider, and avenues to explore, and I hope that this special section can help to keep this conversation going. In the meantime, we can look to Audre Lorde again to think about how anger might help to sustain us in a deeply troubled world: how it can both energise us and provide clarity, allowing us to clearly recognise, identify, and name injustice in our research and activism. Anger's capacity to clarify is deeply important in a context of widespread cultural gaslighting that would have us believe that gender injustice is not real --- don't we know that we have never had it so good? Women's anger has for so long been cast as unreasonable, hysterical, as the opposite of reason; but actually, it is full of the power of insight and understanding.

\section{Acknowledgements}


I am grateful to Helen Wood, Kaitlynn Mendes, and Heather Savigny for comments on earlier drafts of this introduction, and to Mareile Pfannebecker for broader conversations and feedback on other anger-oriented work that has helped me to write this.

\section{References}

Ahmed, Sara. 2017. Living a Feminist Life. Durham: Duke University Press.

Banet-Weiser, Sarah. 2018. Empowered: Popular Feminism and Popular Misogyny. Durham: Duke University Press.

Banet-Weiser, Sarah. 2018a. "Popular Feminism: Feminist Flashpoints.” Los Angeles

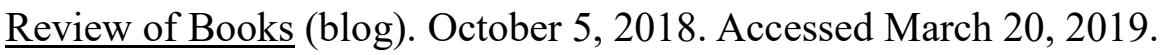

Bates, Laura. 2018. "How Women Are Turning Centuries Of Silence Into Rage”, Elle, September 11.

Berlant, Lauren (2008) The Female Complaint: The Unfinished Business of Sentimentality in American Culture. Durham: Duke University Press

Dobson, Amy Shields \& Akane Kanai. 2018. "From 'can-do' girls to insecure and angry: affective dissonances in young women's post-recessional media". Feminist Media Studies. Online first

Kay, Jilly Boyce. Forthcoming 2019. “Celebritised anger: theorising women's rage, voice and affective injustice through Hannah Gadsby's Nanette" in Gender and Australian Celebrity Culture, edited by Anthea Taylor and Joanna McIntyre. London: Routledge.

Kennedy, Melanie. 2018. Tweenhood: Femininity and Celebrity in Tween Popular Culture. London: I.B. Tauris 
Klorman-Eraqi, Na'ama. 2017. “Underneath we're angry: feminism and media politics in Britain in the late 1970s and early 1980s". Feminist Media Studies, 17 (2): 231-247

Lorde, Audre. 1997 [1981]. "The Uses of Anger” in Women's Studies Quarterly, 25 (1/2), $278-285$

Lundsfryd, Mette Edith. 2017. "Speaking Back to a World of Checkpoints: Oral History as a Decolonizing Tool in the Study of Palestinian Refugees from Syria in Lebanon”. Middle East Journal of Refugee Studies, 2 (1), 74 - 95.

Mendes, Kaitlynn, Jessica Ringrose, and Jessalynn Keller. 2018. Digital Feminist Activism: Girls and Women Fight Back Against Rape Culture. Oxford: Oxford University Press.

Srinivasan, Amia. 2018. “The Aptness of Anger” The Journal of Political Philosophy: 26 (2): $123-144$

White, Rosie. 2013. “Women are angry!” Feminist Media Studies, 13 (3): 415-426

Zsubori, Anna. 2018. "Gender studies banned at university - the Hungarian government's latest attack on equality". The Conversation. October 9. http://theconversation.com/gender-studies-banned-at-university-the-hungariangovernments-latest-attack-on-equality-103150 